\title{
COMPARATIVE STUDY ON SHEAR LAG AND EFFECTIVE WIDTH OF PSC BOX GIRDER
}

\author{
Amruta T. Kawde \\ Post Graduate Student (Structural Engg.) \\ Department of Civil Engg. \\ Saraswati College of Engineering, Mumbai University, \\ Kharghar, Maharashtra ,India
}

\begin{abstract}
The structural system for bridge decks adopted nowadays has been the Box Girder Bridges. However, the box girders suffer from shear lag effect which causes a non-uniform axial stress along its cross-sectional direction which is not true as per the assumption of Simple Beam theory i.e. Plane sections remain plane. In this project, parametric study of three dimensional finite element analysis of a simply supported PSC box girder section for dead load and prestressing using four nodded shell elements is done to evaluate the effect of shear lag. The results obtained show, the effects of geometry of crosssection on the behavior in terms of development of longitudinal stresses in transverse direction of different box girders. The effective flange width is also calculated considering shear lag effects in the design of box girders bridges as per AASHTO LRFD Bridge design specifications (2017). It can be concluded from the present study that the Simple Beam theory is a rough assumption for analysis of box sections. The structure is modeled and analyzed in SOFiSTiK software.
\end{abstract}

Key words: PSC Box Girder Bridge, shear lag, effective flange width, finite element method, SOFiSTiK.

\section{INTRODUCTION}

In recent years, box girder bridges became a popular solution for medium and long span bridges in modern highways and even in railway bridges. This type of bridge is aesthetically pleasing and less vulnerable to environmental conditions compared to open-section bridge. Accordingly, maintenance costs could be significantly reduced throughout the life of the structure. Methods of analysis have developed simultaneously and in the last thirty years progress has been particularly significant. The development of digital computers has enabled engineers to analyse decks with complex crosssections and complicated skew, curved and continuous spans.

The structural action of a box girder bridge deck is more complex than a beam and slab deck because of its three dimensional behaviours consisting of torsion, distortion and bending in longitudinal and transverse directions.

Box-girder analysis and design should take into consideration stresses due to longitudinal bending moment, shear force, torsion, distortion, shear lag and transverse

\author{
Roshni John \\ Associate Professor \\ Department of Civil Engg. \\ Saraswati College of Engineering, Mumbai University, \\ Kharghar, Maharashtra ,India
}

bending. The forces coming on the decks, lead to longitudinal bending and interaction of longitudinal transverse bending.

The overall flexure produces longitudinal membrane normal and shear stress in the elements. Due to wide thin flanges when the axial load is fed into them by shear from the webs, the flange distorts in its plane; the plane sections do not remain plane. This shear lag effect makes the longitudinal flexural stress distribution, non-uniform across the width of top and bottom flanges against the uniform stress obtained from mechanics of material approach.

Thus it is completely necessary to know more about the real shear lag effect happening in the PSC box girder, so the guided design of the box girder can assure the reasonable safety of the bridge. In the present paper, based on the three dimensional Finite Element Analysis (FEA) the shear lag effect and the calculation of effective flange width as per AASTHO is carried out for a simply supported PSC box girder for dead loads.

\section{SHEAR LAG}

The elementary beam theory assumes that a plane section remains a plane after bending. According to the theory the normal stress $\sigma_{\mathrm{x}}$ of a beam cross section, at a point along the transverse direction with coordinates $(\mathrm{y}, \mathrm{z})$, is:

$$
\sigma_{X}=\frac{M_{y}}{I_{z}} \mathrm{y}
$$

Where:

- $\sigma_{\mathrm{x}}=$ Normal stress of the beam along the cros-section

- $\mathrm{M}_{\mathrm{y}}=$ bending moment

- $y=$ distance from neutral axis

- $\mathrm{I}_{\mathrm{z}}=$ second moment of area of the cross-section

This implies a constant stress in the y direction as shown in Fig. 1. (a).This assumption results in a linear distribution of bending stress in the cross section of the beam. The assumption can only be true in a box section if the shear stiffness of the cross section is infinite or if there is no shear force in the box. If the shear force exists in the box, shear flow is developed across the flange and web panels. Due to the shear flow between the flange and the web of the box, the panels displace longitudinally in the way that the middle 


\section{International Journal of Engineering Applied Sciences and Technology, 2019 \\ Vol. 4, Issue 3, ISSN No. 2455-2143, Pages 305-309 \\ Published Online July 2019 in IJEAST (http://www.ijeast.com)}

portion of the flange and web lag behind that of the portion closer to the corner of the box section. This nonlinear longitudinal displacement of the flange and web results in the normal stress distribution as shown in Fig. 1. (b).

For beam cross sections with wide flanges (box, T, or I sections) the longitudinal displacements in the parts of the flanges remote from the web (i.e. in the y direction) lag behind those near the web and due to the action of in-plane shear strain. This phenomenon is called as shear lag.
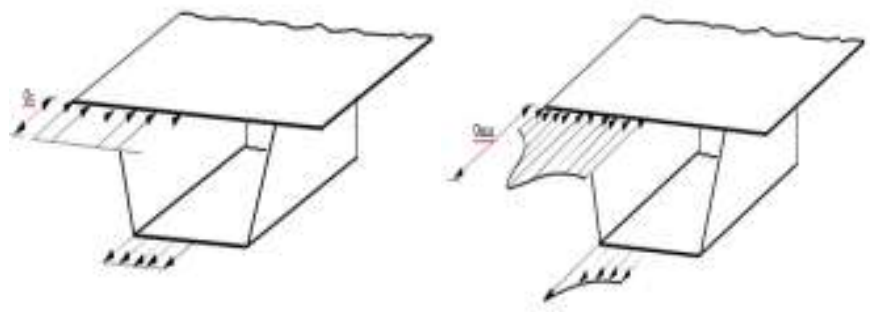

Fig.1. Typical box girder Stress distribution, a) Constant normal stress distribution according to elementary beam theory, b) Non uniform normal stress distribution

\section{EFFECTIVE FLANGE WIDTH}

The effective flange width (be) of a flanged member, as shown in Fig. 1, is defined in Eq. (1) to capture the maximum normal stress in the flange using elementary beam theory in design:

$$
b_{e}=\frac{1}{\sigma_{\max }} \int_{y=0}^{b} \sigma_{x} d_{y}
$$

In which $b=$ width of the flange; $\sigma_{\max }=$ maximum normal stress in the flange, likely near web-flange intersections; $\sigma_{\mathrm{x}}=$ normal stress; and $\mathrm{y}=$ position along the flange. The normal stress distribution at critical sections (i.e., midspans and support locations) is usually used to determine the effective flange width. Note that the definition of effective flange width becomes complex when the deflection of a member rather than the maximum normal stress at a critical section is of interest. In that case, the normal stress distribution at multiple sections along the beam needs to be considered.

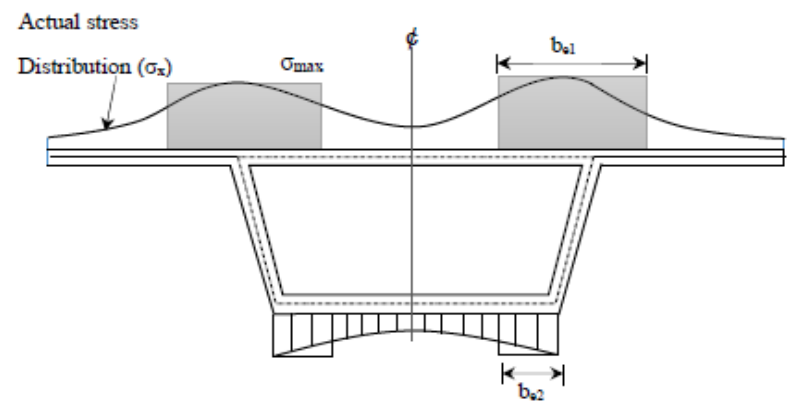

Fig. 2. Definition of effective flange widths in box girder bridge section.

AASHTO design specifications require the use of effective flange width in steel-concrete composite girders, cast in- place/segmental concrete box girders, and steel box girders. Empirical curves are provided for simply supported, cantilever, and continuous steel girders, both with and without stiffeners in Sections 4.6.2.6.1 through 4.6.2.6.4 of the AASHTO Specifications. The existing provisions considers the ratio of the section width (b) over the girder span (L).

\section{GEOMETRIC CONFIGURATION}

To study effect of shear lag in box girder type superstructure, a two lane simply supported single cell PSC box Girder Bridge is considered. The effect of shear lag is studied for different span lengths and the width and depth are kept constant. Two different cross sections namely CS1 and CS2 have been used. For same cross section the width to span ration is varied from 0.32 to 0.36 (CS1). And another cross section with increased cantilever portion the width to span ration is varied from 0.39 to 0.44 (CS2). The analysis is carried out for 2 different spans i.e. for $25 \mathrm{~m}$ and $28 \mathrm{~m}$. In one configuration the width of the cross section is taken as $9 \mathrm{~m}$ and the depth as $2 \mathrm{~m}$ and in another configuration the width of the cross section is taken as $11 \mathrm{~m}$ and the depth as $2 \mathrm{~m}$ The thickness of the top and bottom slab is varied and the web thickness is taken as $500 \mathrm{~mm}$. Fig. 3(a) and 3(b). shows the geometrical properties of one of the configuration CS1 and CS2. Total 8 cables of parabolic profile with jacking force of $2493 \mathrm{kN}$ for $25 \mathrm{~m}$ span and $3128 \mathrm{kN}$ for $28 \mathrm{~m}$ span are used. The cross sectional area of each strand is taken as $140 \mathrm{~mm}^{2}$. The no. of strands are varied so as to balance the dead load moment.

\section{ANALYSIS}

3D Linear finite element analysis was carried out to study the effect of shear lag in PSC box girder bridges. In this analysis to limit the study only uniformly distributed dead loads are considered. For dead load calculation self-weight of the girder and SIDL loads are considered. The densities of concrete and wearing coat are $25 \mathrm{kN} / \mathrm{m}^{3}$ and $22 \mathrm{kN} / \mathrm{m}^{3}$ respectively. To discretize the bridge cross-section four nodded shell element has been employed. The shell element has both bending and membrane capabilities. Both in-plane and normal loads are permitted. The element has six degrees of freedom at each node: translations in the nodal $\mathrm{x}, \mathrm{y}$, and $\mathrm{z}$ directions and rotations about the nodal $\mathrm{x}, \mathrm{y}$, and $\mathrm{z}$-axes. Stress stiffening and large deflection capabilities are included. The element is defined by four nodes, thicknesses and the orthotropic material properties. Orthotropic material directions correspond to the element coordinate directions. Fig. 4. Shows the 3D finite element model of PSC box girder modeled in SOFISTIK . 


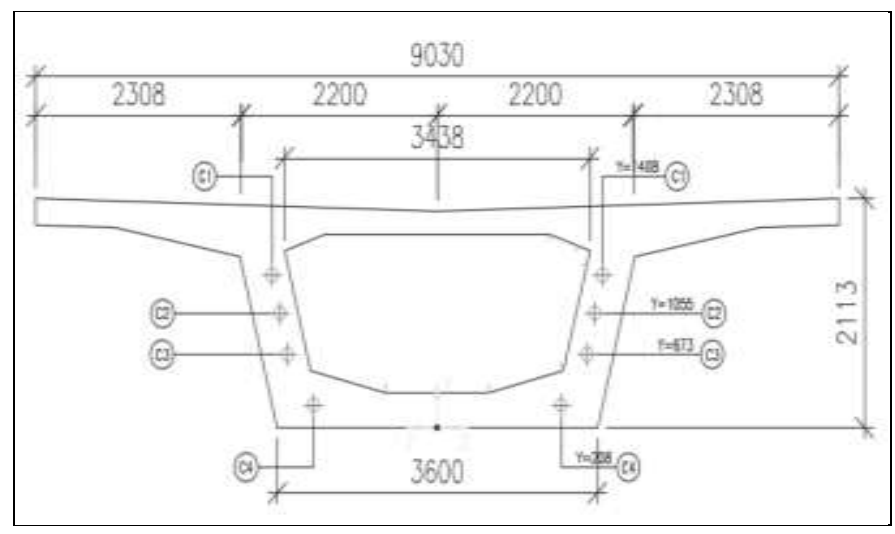

Fig. 3(a). Geometrical properties of cross section and location of cable at the support end for CS1.

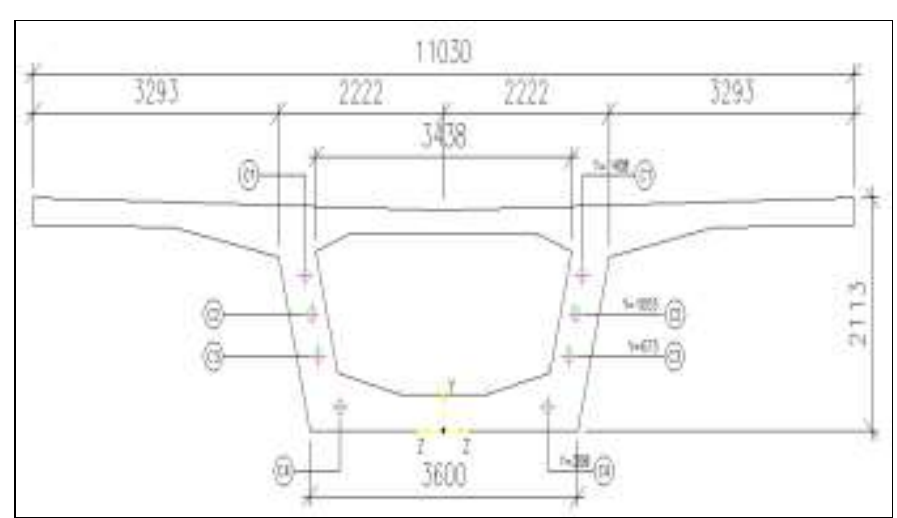

Fig. 3(b). Geometrical properties of cross section and location of cable at the support end.

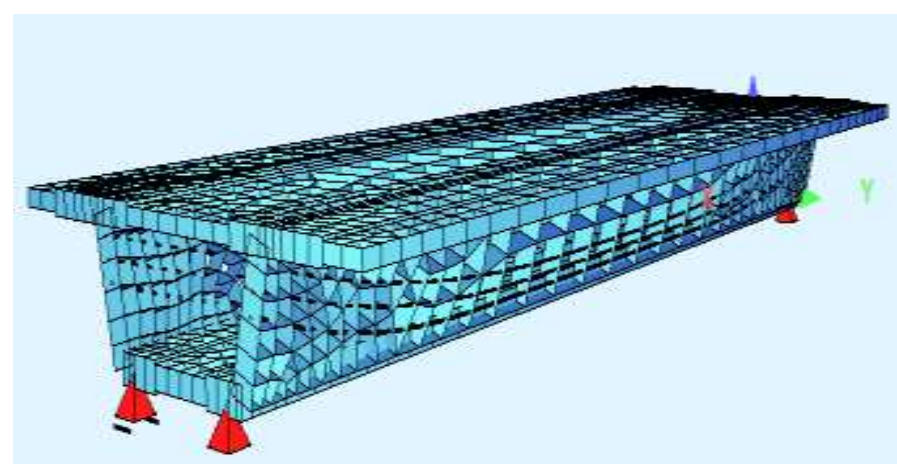

Fig. 4. 3D model of PSC box girder .

\section{Results AND Discussion}

To plot the variation of shear lag in top slab ten key points have been considered and in bottom slab four key points have been considered. To study the effect of shear lag two load cases namely total dead load (DL) which includes self-weight and SIDL and total dead load plus prestressing $(\mathrm{DL}+\mathrm{P})$. The 3D finite element analysis performed determines the longitudinal bending stress variation in the top and bottom slab. The longitudinal bending stress for $9 \mathrm{~m}$ wide and $25 \mathrm{~m}$ and $28 \mathrm{~m}$ span for DL and DL+P load combination are plotted in Fig. 5. and Fig. 6. respectively. And longitudinal bending stress for $11 \mathrm{~m}$ wide and $25 \mathrm{~m}$ and $28 \mathrm{~m}$ span for DL and DL+P load combination are plotted in Fig. 7. and Fig. 8. respectively. Figures below also includes the longitudinal bending stress based on simple bending theory. Based on the results following observations for $9 \mathrm{~m}$ wide cross section can be made as:

a. Top slab is more prone to shear lag effect than the bottom slab. In top slab the shear lag effect observed for total DL for $25 \mathrm{~m}$ span is $38 \%$ and for $28 \mathrm{~m}$ span is $29 \%$.

b. In top slab the shear lag effect observed total $\mathrm{DL}+\mathrm{P}$ for $25 \mathrm{~m}$ span is $35 \%$ and for $28 \mathrm{~m}$ span is $27 \%$.

Based on the results following observations for $9 \mathrm{~m}$ wide cross section can be made as:

a. Top slab is more prone to shear lag effect than the bottom slab. In top slab the shear lag effect observed for total DL for $25 \mathrm{~m}$ span is $53 \%$ and for $28 \mathrm{~m}$ span is $49 \%$.

b. In top slab the shear lag effect observed total $\mathrm{DL}+\mathrm{P}$ for $25 \mathrm{~m}$ span is $49 \%$ and for $28 \mathrm{~m}$ span is $44.4 \%$ and the section with more width to span ratio is more prone to shear lag.

c. In all cases considered the stress calculated using simple bending theory is less compared to the stresses computed by 3D finite element analysis.

d. Calculated effective width shows that for smaller width to span ratio the cross section provided is found to be more effective.

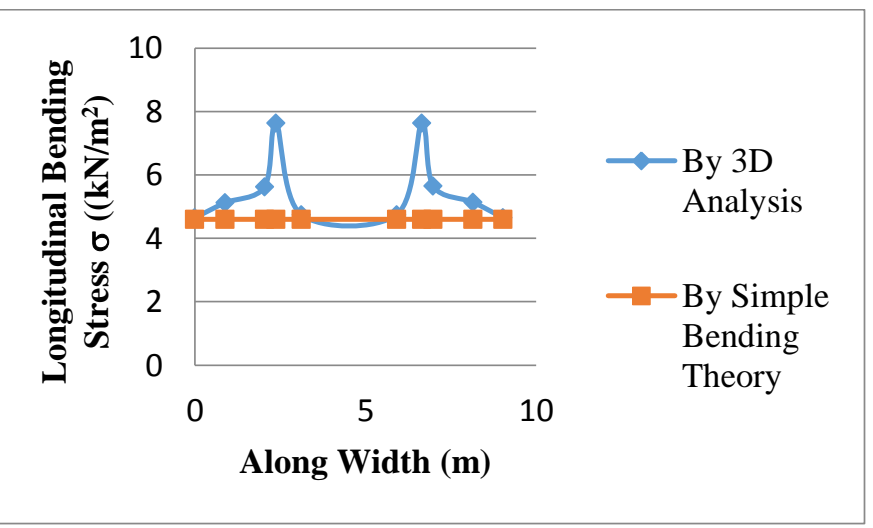

Fig. 5 (a). Variation of stresses for $9 \mathrm{~m}$ wide and $25 \mathrm{~m}$ span for total DL. 
Published Online July 2019 in IJEAST (http://www.ijeast.com)

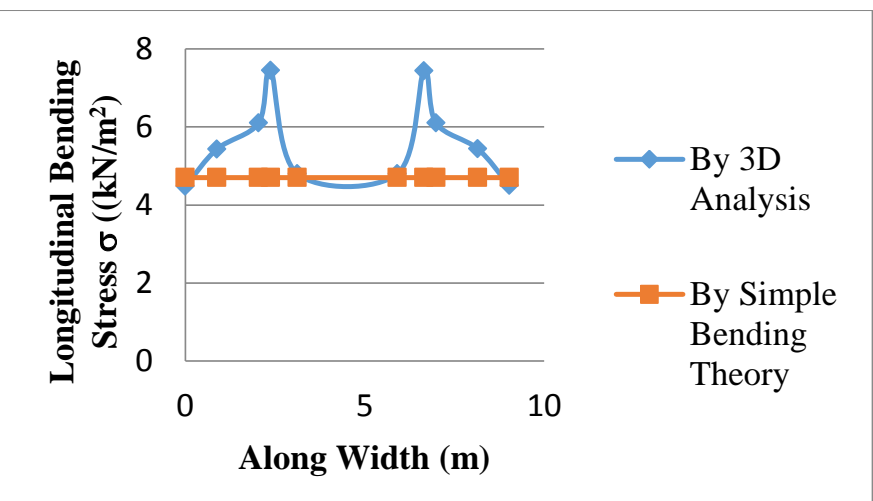

Fig. 5 (b). Variation of stresses for $9 \mathrm{~m}$ wide and $25 \mathrm{~m}$ span for total $\mathrm{DL}+\mathrm{P}$.

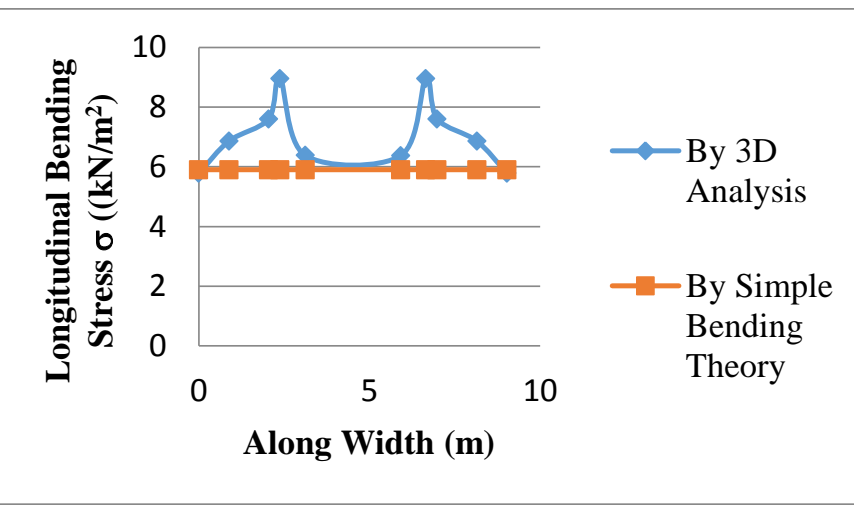

Fig. 6 (a). Variation of stresses for $9 \mathrm{~m}$ wide and $28 \mathrm{~m}$ span for total DL.

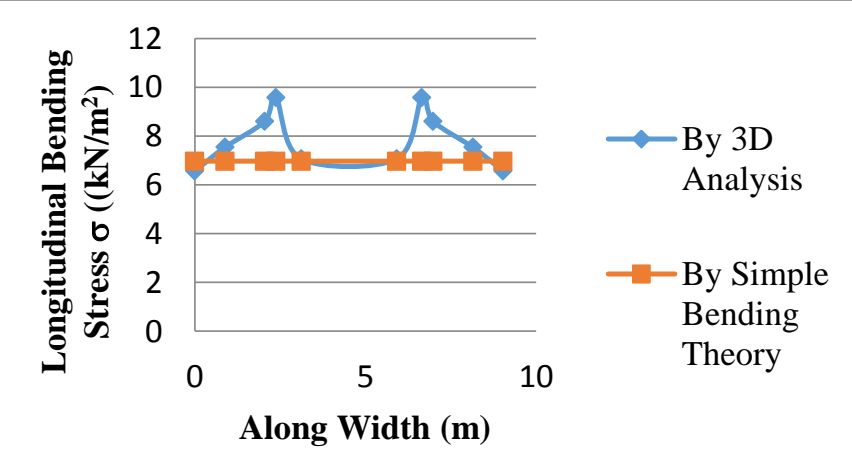

Fig. 6 (b). Variation of stresses for $9 \mathrm{~m}$ wide and $28 \mathrm{~m}$ span for total $\mathrm{DL}+\mathrm{P}$.

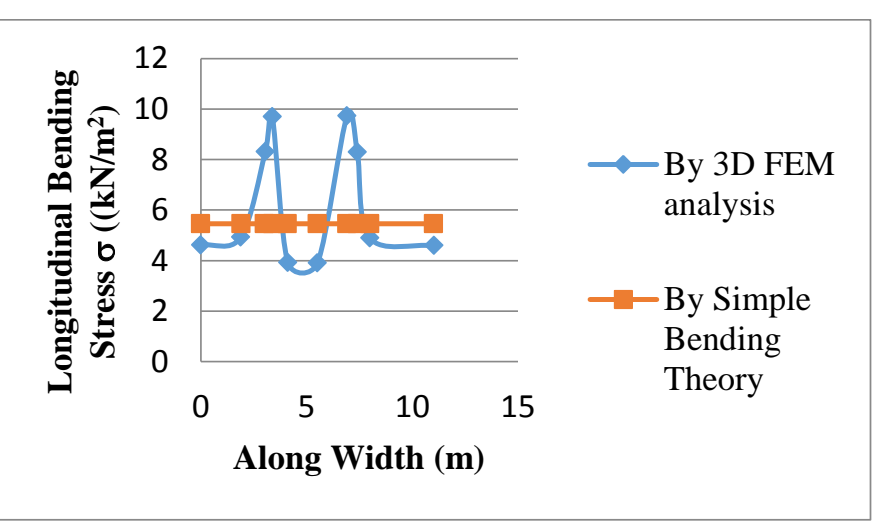

Fig. 7 (a). Variation of stresses for $11 \mathrm{~m}$ wide and $25 \mathrm{~m}$ span for total DL.

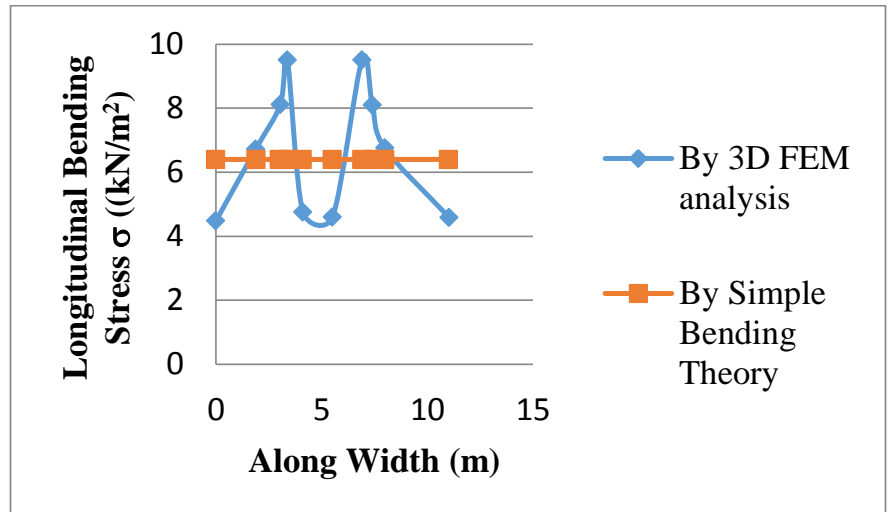

Fig. 7 (b). Variation of stresses for $11 \mathrm{~m}$ wide and $25 \mathrm{~m}$ span for total DL + P.

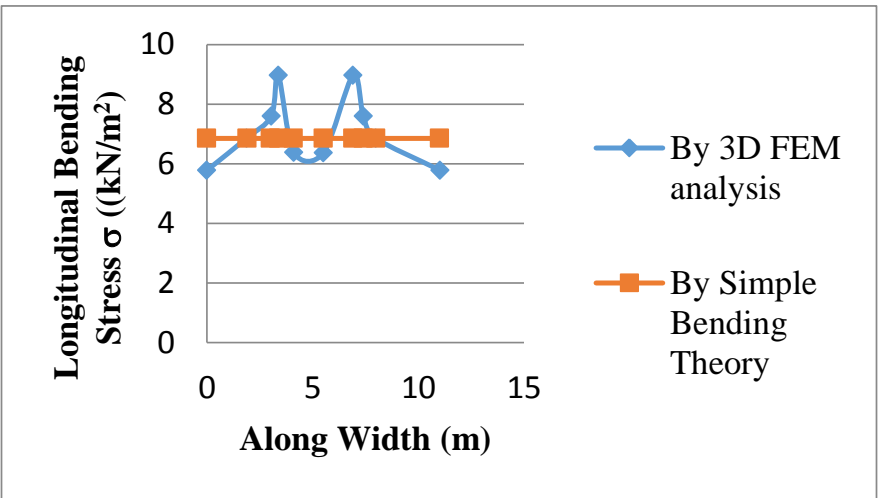

Fig. 8 (a). Variation of stresses for $11 \mathrm{~m}$ wide and $28 \mathrm{~m}$ span for total DL.

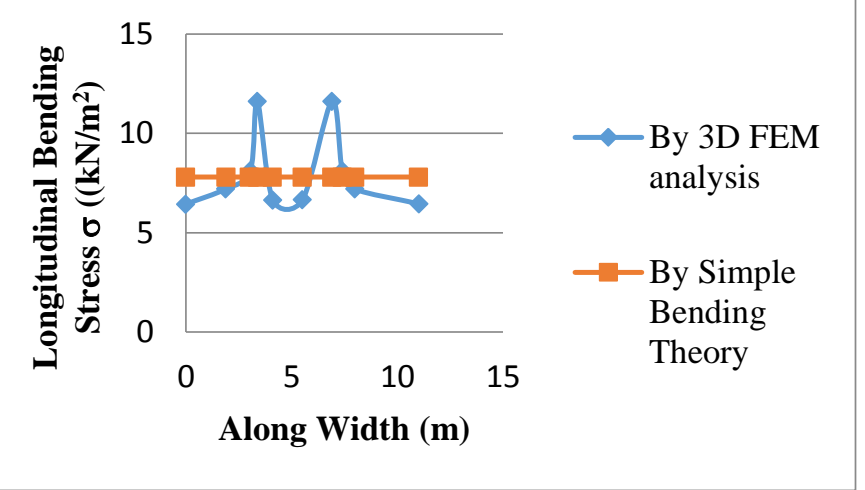

Fig. 8 (b). Variation of stresses for $11 \mathrm{~m}$ wide and $28 \mathrm{~m}$ span for total DL+P. 


\section{International Journal of Engineering Applied Sciences and Technology, 2019 \\ Vol. 4, Issue 3, ISSN No. 2455-2143, Pages 305-309 \\ Published Online July 2019 in IJEAST (http://www.ijeast.com)}

Table. 1. Effective width of $9 \mathrm{~m}$ and $11 \mathrm{~m}$ wide cross section.

\begin{tabular}{|c|c|c|c|c|c|c|c|}
\hline & & \multicolumn{2}{|c|}{ Top slab width } & $\begin{array}{c}\text { Bottom } \\
\text { slab } \\
\text { width }\end{array}$ & \multicolumn{2}{|c|}{$\begin{array}{c}\text { Top slab Effective } \\
\text { Width }\end{array}$} & $\begin{array}{c}\text { Bottom } \\
\text { slab } \\
\text { Effective } \\
\text { Width }\end{array}$ \\
\hline Span (m) & $\begin{array}{c}\text { (b/L) } \\
\text { ratio }\end{array}$ & $\mathbf{b 1}(\mathbf{m})$ & $\mathbf{b 2}(\mathbf{m})$ & $\mathbf{b 3}(\mathbf{m})$ & $\mathbf{b e 1}(\mathbf{m})$ & be2 (m) & be3 (m) \\
\hline 25 & 0.36 & 2.065 & 1.95 & 1.43 & 1.95 & 1.87 & 1.42 \\
\hline 28 & 0.32 & 2.065 & 1.95 & 1.43 & 1.98 & 1.89 & 1.44 \\
\hline 25 & 0.44 & 3.3 & 1.95 & 1.43 & 2.84 & 1.86 & 1.41 \\
\hline 28 & 0.39 & 3.3 & 1.95 & 1.43 & 2.92 & 1.88 & 1.43 \\
\hline
\end{tabular}

\section{CONCLUSION}

From Previous discussion, the following conclusion may be drawn:

a. Shear lag effect caused by dead load and prestress has been studied.

b. The shear lag effect caused by dead load plus prestress remains almost same as the dead load acting alone.

c. It is observed that the section with more width to span ratio is more prone to shear lag

d. CS1 cross section can be considered as most economic section as the effect of shear lag observed is less.

e. The effective width as suggested by AASTHO should be taken into consideration for determining section properties, which will apply to the moment of inertia and the location of neutral axis.

f. Results of linear analysis of a rectangular box girder bridge cross-section have been presented. The results show the behavior in terms of development of deflection and stresses in box girder. This detailed study carried out using SOFISTIK software has clearly brought out the effectiveness of 4- nodded shell elements for analysis of box girder-bridges. It can be concluded from the present study that the simple beam theory is a rough assumption for analysis of box sections.

\section{REFERENCES}

[1] AASHTO (2008), "AASHTO LRFD bridge design specifications." $1^{\text {st }}$ Ed., Washington, D.C.

[2] Reissner, E. (1945). "Analysis of shear lag in box beams by the principle of minimum potential energy." Q. Appl. Math, vol. 4(3), pp. 268-278.

[3] Moffatt, K. R., and Dowling, P. J. (1975). "Shear lag in steel box girder bridges." Struct. Eng, vol. 53(10), pp. 439-448.
[4] Al-Rifaie, W. N., and Evans, H. R. (1979). "An approximate method for the analysis of box girder

bridges that are curved in plan." Proc., Int. Association of Bridges and Structural Engineering, IABSE, pp. 121.

[5] Schlaich, H. S. (1982). "Concrete Box-Girder Bridges." International association of Bridge and Structural Engineers, page 3.

[6] Guo, J. Q., and Fang, Z. Z. (1983). "Analysis of shear lag effect in box girder bridge." Chinese Civ. Eng. J, vol. 16 (1) pp. 1-13.

[7] Chang, S. (1992). "Prestress influence on shear-Lag effect in continuous box-girder bridge." Journal of Structural Engineering, vol. 118, pp. 3113-3121.

[8] Luo, Q., Li, Q., Liu, D. K., and Yang, L.F. (2001). "A modified finite segment method for thin-walled single cell box girders with shear lag." Struct. and Build., Proc., Inst. of Civ. Engrs., London, vol. 146, pp. 41- 46.

[9] Lee, S., Yoo, C., and Yoon, D. (2002). "Analysis of shear lag anomaly in box girders." Journal of Structural Engineering, vol. 128, pp. 1379- 1386.

[10] Kuzmanovic, G. H. (1981). "Shear lag in box girders." $J$ Struct Div ASCE, vol. 107(9), pp. 1701-12.

[11] Luo, Q., Tang, J., and Li, Q. (2002). "Finite segment method for shear lag analysis of cable-stayed bridges." Journal of Structural Engineering, vol. 128, pp. 16171622.

[12] Chang, S. (2004). "Shear lag effect in simply supported prestressed concrete box girder." Journal of Bridge Engineering, vol. 9, pp. 178- 184. 